\title{
The Effect Of Inflation And The Amount Of Money Circulation On Return On Asset (Roa) In Sharia Commercial Banks Period 2011- 2019
}

\author{
Ishak $^{1}$, Arbanur Rasyid ${ }^{2}$, Abdul Nasser ${ }^{3}$, Sulaiman Efendi ${ }^{4}$ \\ ${ }^{1}$ IAIN Padangsidimpuan (Perbankan Syariah, FEBI, IAIN Padangsidimpuan) \\ ${ }^{2}$ IAIN Padangsidimpuan (Hukum Syariah, FEBI, IAIN Padangsidimpuan) \\ ${ }^{3}$ IAIN Padangsidimpuan (Perbankan Syariah, FEBI, IAIN Padangsidimpuan) \\ ${ }^{4}$ IAIN Padangsidimpuan (Perbankan Syariah, FEBI, IAIN Padangsidimpuan) \\ ishak@gmail.com¹, arbanurrasyid@iain-padangsidimpuan.ac.id ${ }^{2}$, hasibuanabdulnasser@iain- \\ padangsidimpuan.ac.id ${ }^{3}$, sulaimanefendi@iain-padangsidimpuan.ac.id ${ }^{4}$
}

\begin{abstract}
ABSTRAK
Latar belakang masalah dalam penelitian ini adalah variabel Return on Asset (ROA) pada tahun 2011-2019 pada Bank Umum Syariah. ROA yang mengalami fluktuasi ini dipengaruhi oleh faktor eksternal perusahaan seperti inflasi dan jumlah uang beredar. Sehingga rumusan masalah dalam penelitian ini adalah apakah inflasi beredar berpengaruh terhadap ROA, apakah jumlah uang beredar berpengaruh terhadap ROA, dan apakah inflasi dan jumlah uang beredar dan secara beresama-sama berpengaruh terhadap ROA. Penelitian ini bertujuan untuk mengetahui pemgaruh inflasi dan jumlah uang beredar terhadap ROA pada Bank Umum Syariah periode 2011-2019. Penelitian ini merupakan penelitian kuantitatif. Sampel dalam penelitian ini menggunakan teknik sampel jenuh. Menggunakan semua populasi mejadi sampel, didapatkan dari 32 laporan keuangsn. Teknik analisis data yang digunakan time series dari tahun 2011 sampai 2019. Pengelolahan data menggunakan aplikasi SPSS versi 22. Teknik analisis data yang digunakan adalah uji statistik, asumsi klasik, deskriptif, uji normalitas, uji multikoleniearitas, uji heteroskedastistas, uji autokolerasi, uji hipotesis, analisis regresi linear berganda, uji koefisien determinasi. Hasil penelitian secara pasrial (Uji t) menunjukkan bahwa variabel inflasi tidak berpengaruh terhadap ROA dan variabel jumlah uang beredar berpengaruh negatif terhadap ROA. Sedangkan secara simultan (Uji F) menunjukkan bahwa variabel inflasi dan jumlah uang beredar berpengaruh secara simultan terhadap ROA. Uji daterminasi $\left(R^{2}\right)$ dalam penelitian ini sebesar $44,4 \%$ yang dipengaruhi oleh variabel dalam penelitian ini, sedangkan 55,6\% dipengaruhi oleh variabel lain yang peneliti tidak cantumkan dalam penelitian ini.
\end{abstract}

Kata Kunci: Retrun on Asset (ROA), Inflasi, Jumlah Uang Beredar

\section{ABSTRACT}

The background of the problem in this study is the variable Return on Assets (ROA) in 2011-2019 at Islamic Commercial Banks. This fluctuating ROA is influenced by external factors such as inflation and the money supply. So that the formulation of the problem in this study is whether the inflation in circulation has an effect on ROA, whether the money supply affects ROA, and whether inflation and the money supply together have an effect on ROA. This study aims to determine the effect of inflation and the money supply on ROA in Islamic Commercial 
POINT Vol. 1, No. 1, Jul 2020

Banks for the period 2011-2019. This research is a quantitative research. The sample in this study used a saturated sampling technique. Using all of the population as a sample, we get 32 financial reports. The data analysis technique used time series from 2011 to 2019. Data processing used the SPSS version 22 application. The data analysis techniques used were statistical tests, classical assumptions, descriptive, normality test, multicollinearity test, heteroscedastical test, autocoleration test, hypothesis testing, multiple linear regression analysis, test the coefficient of determination. The results of the research ( $t$ test) show that the inflation variable has no effect on ROA and the money supply variable has a negative effect on ROA. Meanwhile, simultaneously (Test F) shows that the inflation variable and the money supply have a simultaneous effect on ROA. The datermination test $\left(R^{2}\right)$ in this study was $44,4 \%$ which was influenced by the variables in this study, while $55,6 \%$ was influenced by other variables that the researcher did not include in this study.

Keywords: Return On Asset, Inflation, Money Supply

\section{A. PENDAhULUAN}

Mendengar kata bank sebenarnya tidak asing lagi bagi kita, terutama yang hidup di perkotaan. Bahkan, di pedesaan sekalipun saat ini kata bank bukan merupakan kata asing dan aneh. Menyebut kata bank setiap orang selalu mengaitkannya dengan uang sehingga selalu saja ada tanggapan bahwa yang berhubungan dengan bank selalu ada kaitannya dengan uang. Hal ini tidak salah karena bank memang merupakan lembaga keuangan atau perusahaan yang bergerak dibidang keuangan. Sebagai lembaga keuangan bank menyediakan berbagai jasa keuangan. Di negara-negara maju bank bahkan sudah merupakan kebutuhan utama bagi mayarakat setiap kali bertransaksi. (Kasmir,2012:01).

Mengingat pentingnya dunia perbankan bagi pertumbuhan ekonomi, maka tidak mengherankan bahwa sebagai tolak ukurnya selalu dilihat dari sisi kinerja keuangan bank tersebut selama periode tertentu. Bisnis perbankan adalah bisnis kepercayaan untuk itu bank harus mampu menunjukkan kreditibilitasnya sehingga akan semakin banyak masyarakat yang bertransaksi di bank tersebut. Dalam teori keuangan, konsep profitabilitas sering digunakan sebagai indikator dalam mengukur kinerja perusahaan.(Harmono, 2009:110).

Ukuran profitabilitas yang digunakan adalah Return On Asset (ROA) pada industri perbankan adalah rasio yang menggambarkan kemampuan bank dalam mengelola dana yang diinvestasikan dalam keseluruhan aktiva yang menghasilkan keuntungan. (ROA) adalah gambaran produktivitas bank dalam mengelola dana sehigga menghasilkan keuntungan. (Fretty Welta dan Lemiyan, 2017: 85).

Dalam pelaksanaan kegiatan operasionalnya, bank tidak terlepas dari pengaruh kondisi perekonomian. Kaitannya dalam hal ini, faktor-faktor ekonomi makro seperti neraca pembayaran, pendapatan nasional, produk dosmetik bruto dan nasional bruto, gross dosmetik produk, tingkat pertumbuhan ekonomi, tingkat inflasi, tingkat pengangguran, nilai tukar palas, jumlah uang 
beredar dan suku bunga.(Sadono Sukirno, 2006:26).

Dibidang moneter, laju inflasi juga merupakan variabel makro ekonomi yang dapat berpengaruh terhadap profitablitas. Laju inflasi merupakan gambaran harga-harga. harga yang mebubung tinggi tergambar dalam inflasi yang tinggi, begitu juga sebaliknya. Laju inflasi yang tinggi dan tidak terkendali dapat menggangu upaya perbankan dalam perbankan dalam pengerahan dana masyarakat. Karena tingkat inflasi yang tinggi menyebabkan tingkat suku bunga riil menjadi menurun. Fakta demikian akan mengurangi hasrat masyarakat untuk menabung sehingga pertumbuhan perbankan yang bersumber dari masyarakat akan menurun.(Aulia Pohan, 2008:52).

Perkembangan jumlah uang beredar mencerminkan atau seiring dengan perkembangan ekonomi. Bila perekonomian tumbuh dan berkembang, jumlah uang beredar juga akan bertambah, sedang komposisinya berubah. Bila perekonomian makin maju, porsi penggunaan uang kartal makin sedikit karena digantikan dengan uang giral atau near money. Bila perekonomian makin meningkat, maka komposisi M1 dalam peredaran uang semakin kecil, sebab porsi uang kuasi makin besar. (Amirus Sodiq, 2014:219).

Bank komersial atau bank umum berperan dalam penciptaan uang giral melalui melalui pemberian kredit. Perbankan yang sehat akan membuat penciptaan uang giral berjalan dengan mulus, ditunjukkan dengan dengan rendahnya kredit macet. Sebaliknya, meningkatnya kredit macet menurunkan aset bank, dan dapat menyebabkan bank menjadi kurang sehat/insolvent (kewajiban lebih besar daripada aset). Kondisi ini akan memicu nasabah untuk menarik uangnya dari bank dan menyimpannya dalam bentuk aset lainnya, misalnya tanah, rumah, dan benda lainnya (atau bahkan menyimpan di bawah bantal). Jika hal ini terjadi, maka penciptaan uang giral menjadi terhambat, jumlah uang beredar berkurang dan begitu pula pertumbuhan ekonomi.(Ktu Silvana, 2009:33).

Sehingga dari pemaparan di atas peneliti menemukan adanya hal yang betentangan dengan teori yang ada, dimana apabila inflasi meningkat maka ROA akan menurun dan sebaliknya. Apabila jumlah uang beredar (JUB) meningkat maka ROA juga meningkat dan sebaliknya. Berdasarkan fenomena yang ada peneliti ini, merasa tertarik melakukan penelitian yang berjudul "Pengaruh Inflasi dan Jumlah Uang Beredar Terhadap Return On Asset (ROA) pada Bank Umum Syariah Periode 2011-2019".

\section{B. METODE}

Jenis penelitian yang digunakan dalam penelitian ini adalah penelitian kuantitatif. Penelitian kuantatif merupakan penelitian dengan menggunakan data kuantitatif (data yang berbentuk angka atau dapat diangkakan), atau data yang dukur dalam suatu skala numerik (angka). 
Populasi dalam penelitian ini adalah laporan keuangan Bank Umum Syariah dalam bentuk per-triwulan Return on Asset (ROA), Jumlah Uang Beredar (JUB) dan Inflasi dari tahun 2011-2019. Dengan demikian penelitian ini sebanyak 36.

Adapum sampel penelitian yaitu sebanyak 32 sampel, 1 tahun diambil 4 bulan, jadi sampel yang di ambil kurun waktu 9 tahun $x$ triwulan ( $9 \times 4=36$ sampel).

Penelitian ini menggunakan data sekunder. Adapun data yang digunakan dalam penelitian bersumber Bank indonesia melaui situs resmi www.bi.go.id yaitu data inflasi, situs resmi Otoritas Jasa Keuangan www.ojk.go.id yaitu data Return On Asset (ROA) dan kementerian perdagangan Republik Indonesia melaui situs resmi www.kemendag.go.id yaitu data Jumlah Uang Baeredar.

\section{HASIL DAN PEMBAHASAN}

Hasil Uji Statistik Deskriptif

Tabel 1

Hasil Uji Statistik Deskriptif

Descriptive Statistics

\begin{tabular}{|c|r|r|r|r|r|}
\hline & & $\begin{array}{c}\text { Minimu } \\
\mathrm{m}\end{array}$ & $\begin{array}{c}\text { Maximu } \\
\mathrm{m}\end{array}$ & Mean & $\begin{array}{c}\text { Std. } \\
\text { Deviatio } \\
\mathrm{n}\end{array}$ \\
\hline Roa & $\mathrm{N}$ &, 49 & 2,39 & 1,3964 &, 54464 \\
Inflasi & 36 & 2,48 & 8,40 & 4,7419 & 1,76786 \\
Jub & 36 & 2451356, & 6136551, & 434357 & 1101949, \\
& 92 & 81 & 7,4339 & 19530 \\
Valid N & 36 & & & & \\
(listwise) & & & & & \\
\hline
\end{tabular}

Sumber: Data diolah, 2020

Berdasarkan tabel 4.5 di atas dapat diketahui bahwa $\mathrm{N}$ menyatakan jumlah sampel
POINT Vol. 1, No. 1, Jul 2020 yang diambil dalam penelitian yaitu dari tahun bulan Maret 2011 sampai 2019 pertriwulan yang berjumlah 36 bulan. dari tabel di atas diketahui bahwa minimum dari variabel Inflasi yaitu 2,48 persen, nilai maksimumnya sebesar 8,40 persen. Nilai rata-rata variabel inflasi sebesar 4,7419, sedangkan nilai standar deviasi dari variabel inflasi sebesar 1,76786.

Variabel jumlah uang beredar memiliki minimum sebesar 2.451.365,92 Milyar Rupiah, nilai maksimumnya sebesar 6.136.551,81 Milyar Rupiah. Nilai rata-rata variabel jumlah uang beredar sebesar 4.343.577,4339. Sedangkan nilai standar deviasi dari jumlah uang beredar sebesar 99.712,60291.

Sementara variabel Return on Asset (ROA) memiliki minimum sebesar 0,49 persen, nilai maksimum Return on Asset (ROA) sebesar 2,39 persen . Nilai rata-rata variabel Return on Asset (ROA) sebesar 1,3578. Sedangkan nilai standar deviasi Return on Asset (ROA) sebesar 1.101.949,19530.

Uji Normalitas

Gambar 1 Hasil Uji Normalitas

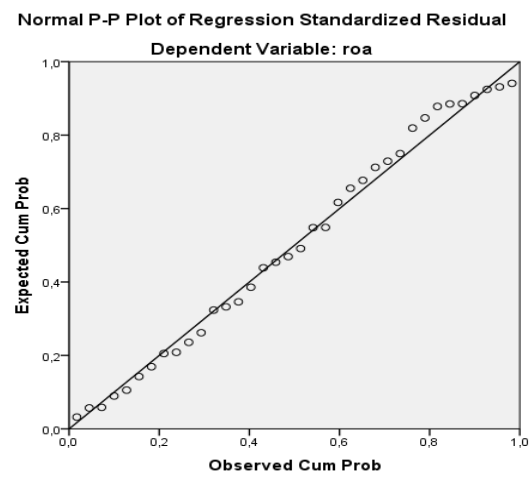

Sumber: Data diolah, 2020 
Coefficientsa

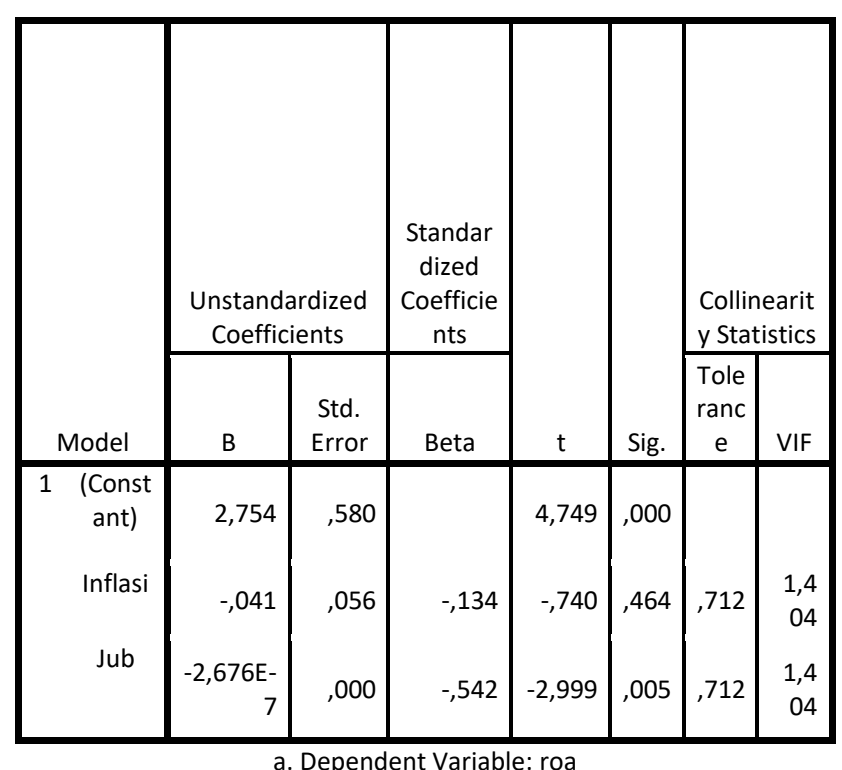

Berdasarkan gambar 4.3 Normal P-Plot

of Regression Standardized Residual di atas terlihat bahwa titik-titik menyebar di sekitar garis diagonal dan mengikuti garis diagonal. Selain itu data yang berdistribusi normal juga dapat di ketahui melalui uji normalitas dengan Kolmogrov-Smirnov. Data variabel yang baik adalah jika probabilitasnya atau $p>0,05$. Hasil uji normalitas dapat dilihat pada tabel berikut.

Tabel 2

Hasil Uji Normalitas

One-Sample Kolmogorov-Smirnov Test

\begin{tabular}{|rc|r|}
\hline & & \multicolumn{2}{|c|}{$\begin{array}{c}\text { Unstandardized } \\
\text { Residual }\end{array}$} \\
\hline \multicolumn{2}{|c|}{$\mathrm{N}$} & 36 \\
Normal & Mean &, 0000000 \\
Most Extreme $\quad$ Std. Deviation & Absolute &, 7684985 \\
Differences & Positive &, 079 \\
& Negative &, 054 \\
Test Statistic &,- 079 \\
Asymp. Sig. (2-tailed) &, 079 \\
\end{tabular}

a. Test distribution is Normal.

b. Calculated from data.

c. Lilliefors Significance Correction.

d. This is a lower bound of the true significance.

Sumber: Data diolah, 2020
Berdasarkan tabel 4.6 One-Sample Kolmogorov-Smirnov Test di atas dapat diketahui bahwa signifikansi (Asymp. Sig. 2tailed) sebesar $0,200>0,05$. Dengan demikian, dapat disimpulkan bahwa regresi telah memenuhi uji normalitas.

Hasil Uji Multikolineariatas

Tabel 3

Hasil Uji Multikolinearitas

Sumber : Data diolah, 2020

Berdasarkan tabel $4.7 \mathrm{di}$ atas dapat diketahui bahwa nilai tolerance kedua variabel lebih besar dari 0,10 dan kurang dari 10 . Dimana nilai tolerance dari variabel inflasi sebesar 0,712 dan nilai VIF sebesar 1,404. Nilai tolerance jumlah uang beredar sebesar 0,712dan nilai VIF sebesar 1,404. Maka dapat disimpulkan bahwa tidak terjadi multikolinearitas antarvariabel independennya. Hasil Uji Heteroskedastisitas

Tabel 4

\section{Hasil Uji Heteroskedastisitas Metode Glejser}

Sumber: Data diolah, 2020

Berdasarkan gambar 4.8 menunjukkan dapat diketahui bahwa nilai signifikan bereda lebih besar dari 0,05 maka dapat tidak terjadi heteroskedastisitas.

Hasil Uji Autokolerasi

Tabel 5

Hasil Uji Autokolerasi 
Berdasarkan tabel 4.9 di atas dapat diketahui bahwa Durbin-Watson sebesar 1,968. Jadi artinya $\mathrm{dU}<\mathrm{d}<4$-Du maka (tidak terjadi autokorelasi) 1,5872 $<1,968<2,4128$.

Sehingga dapat disimpulkan bahwa tidak terjadi Autokolerasi pada model regresi dalam penelitian.

Uji Koefisien regresi secara parsial (uji t)

Uji Koefisien Regresi Secara Simultan (uji F)

Tabel 7

Hasil Uji Simultan (Uji F)

ANOVAa

\begin{tabular}{|c|c|c|c|}
\hline Model & $\begin{array}{l}\text { Sum of } \\
\text { Squares }\end{array}$ & Df & Mean Square \\
\hline Regression & 2,424 & 2 & 1,21 \\
\hline
\end{tabular}

Coefficientsa

\begin{tabular}{|c|c|c|c|c|c|}
\hline \multirow[b]{2}{*}{ Model } & \multicolumn{2}{|c|}{$\begin{array}{c}\text { Unstandardized } \\
\text { Coefficients }\end{array}$} & \multirow{2}{*}{$\begin{array}{c}\text { Standardized } \\
\text { Coefficients } \\
\text { Beta }\end{array}$} & \multirow[b]{2}{*}{$\mathrm{t}$} & \multirow[b]{2}{*}{ Sig. } \\
\hline & $B$ & Std. Error & & & \\
\hline $1 \quad$ (Constant) & 2,754 &, 580 & & 4,749 & 000 \\
\hline inflasi &,- 041 & ,056 & -134 &,- 740 & , 464 \\
\hline Jub & $-2,676 \mathrm{E}-7$ & ,000 &,- 542 & 2,999 & ,005 \\
\hline
\end{tabular}

Tabel 6 Hasil Uji Parsial (Uji t)

Sumber: Data diolah, 2020

Berdasarkan tabel di atas, Inflasi dapat diketahui bahwa thitung<ttabel ($0,740<1.69236)$ maka maka HO diterima. Maka dapat disimpulkan bahwa inflasi tidak berpengaruh terhadap ROA. Sedangkan Jumlah Uang Beredar dapat diketahui bahwa thitung $>$ ttabel $(-2,999>1.69913)$ Ha diterima. Maka disimpulkan bahwa jumlah uang beredar berpengaruh negatif terhadap ROA. Nilai thitung menunjukkan arah positif, maka dapat diartikan bahwa jika jumlah uang beredar meningkat bahwa ROA menurun.

\begin{tabular}{|c|r|r|r|}
\hline Residual & 7,959 & 33 &, 24 \\
Total & 10,382 & 35 & \\
\hline
\end{tabular}

a. Dependent Variable: roa

b. Predictors: (Constant), jub, inflasi Sumber: Data diolah, 2020

Berdasarkan tabel di atas dapat di

diketahui bahwa Fhitung >Ftabel (13.374>2.93) maka HO ditolak dan Ha diterima. Maka disimpulkan bahwa inflasi dan jumlah uang beredar berpengaruh secara simultan terhadap ROA pada Bank Umum Syariah periode 20112019.

Uji Koefisien Determinasi (R2)

Tabel 8

Hasil Uji Koefisiean Determinasi (R2)

Model Summaryb

\begin{tabular}{|c|c|c|c|r|}
\hline Model & $\mathrm{R}$ & R Square & $\begin{array}{c}\text { Adjusted R } \\
\text { Square }\end{array}$ & $\begin{array}{r}\text { Std. Error of } \\
\text { Estimate }\end{array}$ \\
\hline
\end{tabular}


1 , $693 a$ , 480

a. Nilai konstahta (a) adalah 2754 , artinya jika 'inffas dan jumlah 428 upng beredar

a. Predictors: (Constant), jub, infrilasinya 0 , maka ROA nilainya 2,754

Sumber: Data diolah, 2020

b. Dependent Variable:broa Nilai koefisien regresi variabel inflasi (b1) Berdasarkan tabel 4.12 di atas dapat dilihat hasil uji koefisien determinasi (R2) bahwa nilai ajusted $\mathrm{R}$ square adalah 0,444 atau sama dengan $44,4 \%$ artinya bahwa inflasi dan jumlah uang beredar mampu menjelaskan variabel dependen atau ROA sebesar $44,4 \%$.

Sedangkan sisanya $55.6 \%$ dijelaskan oleh variabel lain yang tidak di masukkan dalam model ini atau masih ada faktor lain yang mempengaruhi Return on Asset (ROA).

Hasil Penelitian Regresi Linear Berganda

Tabel 9

Hasil Analisis Regresi Linear Berganda Coefficientsa

\begin{tabular}{|c|c|c|c|c|c|c|c|}
\hline \multirow[b]{2}{*}{ Model } & \multicolumn{2}{|c|}{$\begin{array}{l}\text { Unstandardized } \\
\text { Coefficients }\end{array}$} & \multirow{2}{*}{\begin{tabular}{|c|}
$\begin{array}{c}\text { Standardiz } \\
\text { ed } \\
\text { Coefficient } \\
\text { s }\end{array}$ \\
Beta \\
\end{tabular}} & \multirow[b]{2}{*}{$\mathrm{t}$} & \multirow[b]{2}{*}{ Sig. } & \multicolumn{2}{|c|}{$\begin{array}{c}\text { Collinearity } \\
\text { Statistics }\end{array}$} \\
\hline & B & Std. Error & & & & $\begin{array}{c}\text { Toleran } \\
\text { ce }\end{array}$ & VIF \\
\hline $\begin{array}{cc}1 & \text { (Consta } \\
& n t)\end{array}$ & 2,754 & ,580 & & 4,749 & ,000 & & \\
\hline inflasi &,- 041 & ,056 &,- 134 &,- 740 & 464 & ,712 & 1,404 \\
\hline Jub & $-2,676 \mathrm{E}-7$ & ,000 &,- 542 & $-2,999$ & ,005 & ,712 & 1,404 \\
\hline
\end{tabular}

a. Dependent Variable: roa adalah sebesar $-0,041$

c. Nilai koefisien regresi variabel jumlah uang beredar (b2) adalah sebesar artinya 2,676 bahwa setiap peningkatan inflasi sebesar 1 persen, maka akan menurunkan ROA sebesar 2,676 persen dengan asumsi variabel lain nilainya tetap.

Berdasarkan hasil penelitian yang diuraikan di atas, untuk pengaruh variabel independen (inflasi dan jumlah uang beredar) terhadap variabel dependen (ROA) pada Bank Umum Syariah periode 2011-2019 baik secara parsial maupun simultan adalah sebagai berikut:

1.

Pengaruh Inflasi terhadap Return On Asset (ROA) Pada Bank
Sumber: Data diolah, 2020

Hasil uji regresi linear berganda pada

tabel 4.13 dimana coefficients dapat dilihat dari hasil uji regresi berganda, maka persamaan dalam penelitian ini adalah:

$\mathrm{ROA}=\mathrm{a}+\mathrm{b} 1 \operatorname{lnflasi}+\mathrm{b} 2 \mathrm{JUB}+\mathrm{e}$

$\mathrm{ROA}=2,754-0,041$ Inflasi- 2,676JUB + e

Penjelasan dari persamaan di atas adalah sebagai berikut:
Umum Syariah Periode 2011-2019

Berdasarkan hasil penelitian menunjukkan dapat dinyatakan bahwa inflasi tidak berpengaruh terhadap ROA.

Hal ini tidak sesuai dengan teori Aulia Pohan yang menyatakan bahwa laju inflasi yang tinggi dan tidak terkendali dapat mengganggu upaya perbankan dalam 
penegerahan dana masyarakat, karena tingkat inflasi yang tinggi menyebabkan tingkat suku bunga riil menurun. Fakta demikian akan mengurangi hasrat masyarakat untuk menabung sehingga pertumbuhan dana yang bersumber dari masyarkat akan menurun(Aulia Pohan, 2008:52). Penelitian ini didukung dengan penelitian yang dilakukan oleh Anas Tinton Saputra, Aris Putrama, Fretti Welta, dan Ibnu Seyna Riyanto bahwa inflasi tidak berpengaruh pada ROA.

Inflasi tinggi maka masyarakat lebih percaya terhadap perbankan syariah dibandingkan dengan perbankan konvensional. Kepercayaan masyarakat tersebut juga dimungkinkan karena adanya pengalaman historis pada saat terjadi krisis ekonomi tahun 1997, dimana pada masa tersebut tingkat inflasi di indonesia sangat tinggi dan akhirnya mengakibatkan banyak bank konvesional yang mengalami kebangkrutan akibat menerapkan tingkat untuk mengimbangi laju inflasi serta untuk menarik nasabah agar tetap menempatkan dananya sehingga terjadi negarif spread dan pada akhirnya bank tersebut tidak dapat mengembalikan dana masyarakat yang telah disimpan beserta bunganya.

2. Pengaruh Jumlah Uang Beredar Terhadap Return On Asset (ROA) Pada Bank Umum Syariah Periode 2011-2019
POINT Vol. 1, No. 1, Jul 2020

Berdasarkan hasil penelitian menunjukkan dapat dinyatakan bahwa dengan secara parsial jumlah uang beredar berpengaruh negatif terhadap ROA.

Hal ini tidak sesuai dengan teori Ktut Silvanita yang menyatakan bahwa bahwa bank komersial atau bank bank umum berperan dalam penciptaan uang giral melalui pembiayaan. Perbankan yang sehat akan membuat penciptaan uang giral berjalan dengan mulus yang di tandai dengan rendahnya pembiayaan macet. Sebaliknya jika pembiayaan macet meningkat maka hal tersebut akan menururnkan asset bank dan kondisi ini dapat memicu masyarakat untuk menarik uangnnya dan menyimpannya dalam berbentuk aset lain seperti tanah rumah dan lain-lain. Jika hal ini terjadi, maka penciptaan uang giral terhambat dan jumlah uang beredar berkurang.(Ktut Silvana, 2009:33)

Hasil penelitian ini didukung dengan hasil penelitian terdahulu Ibnu Seyna Riyanto menyatakan jumlah uang beredar negatif berpengaruh terhadap ROA. Meningkatnya jumlah uang beredar di masyarakat akan diikuti meningkatnya suku bunga yang di terapkan pemerintah sehingga mengkibatkan nasabah memindahkan dananya ke bank konvensional, untuk memperoleh pengembalian yang tinggi. Naiknya suku bunga bank akan mempengaruhi kegiatan operesional bank syariah yaitu dalam hal 
pembiayaan dan penyaluran dana, bila hal tersebut terjadi maka pendapatan dan profit bank syariah akan menurun.

3. Pengaruh Inflasi dan Jumlah Uang Beredar Terhadap Return On Asset (ROA) Pada Bank Umum Syariah Periode 2011-2019

Berdasarkan hasil penelitian, ini disimpulkan bahwa inflasi dan jumlah uang beredar berpengaruh secara simultan (bersama) terhadap ROA pada Bank Umum Syariah periode 2011-2019. Hasil penelitian ini didukung dengan yang dilakukan oleh Anas Tinton Saputra, Amirus Sodiq, dan Ibnu Seyna Riyanto.

Menurut Rivai profitabilitas bank dapat dipengaruhi oleh dua faktor, yaitu faktor internal dan faktor eksternal. Faktor internal merupakan faktor yang berasal dari dalam bank seperti produk bank, kualitas layanan, kebijakan suku bunga atau bagi hasil di bank syariah, dan reputasi bank. Sedangkan faktor eksternal merupakan faktor yang bersumber dari luar bank, seperti kondisi perekonomian, kebijakan pemerintah, kondisi perkembangan pasar uang dan pasar modal, serta peraturan Bank Indonesia. Faktor eksternal yang dapat mempengaruhi profitabilitas bank yaitu makroekonomi. Beberapa variabel makroekonomi yang mempengaruhi profitabilitas bank antara lain inflasi, tingkat suku bunga $\mathrm{BI}$ rate, produk domestik bruto, dan jumlah uang beredar.

\section{PENUTUP}

\section{Kesimpulan}

Berdasarkan hasil pengelolahan data dari penelitian yang berjudul "Pengaruh Inflasi dan Jumlah Uang Beredar Terhadap Return On Asset (ROA) pada Bank Umum Syariah Periode 2011-2019" dapat diambil kesimpulan sebagai berikut:

1. Inflasi tidak berpengaruh terhadap return on asset (ROA) pada Bank Umum Syariah periode 2011-2019

2. Jumlah uang beredar jumlah uang beredar berpengaruh negatif terhadap return on asset (ROA) pada Bank Umum Syariah periode 2011-2019

3. Inflasi dan jumlah uang beredar berpengaruh secara simultan terhadap return on asset (ROA) pada Bank Umum Syariah periode 2011-2019.

\section{Saran}

Berdasarkan kesimpulan yang ada makas perlunya peningkatan jumlah inflasi dan jumlah uang yang beredar.

\section{DAFTAR PUSTAKA}

Ali Hardana, ANALISIS FAKTOR-FAKTOR YANG MEMPENGARUHI PENDAPATAN INDUSTRI KECIL DI KOTA PADANGSIDIMPUAN DAN KABUPATEN TAPANULI SELATAN
Hardana Tazkir : Jurnal Penelitian IImu-ilmu Sosial dan Keislaman (iain-padangsidimpuan.ac.id)

Adiwarman A. Akarim, Bank Islam Analisis Fiqih dan Keuangan, Jakarta: Rajawali Pers, 2009

Aulia Pohan, Potret Kebijakan Moneter Indonasia, Jakarta: PT RajaGrafindo Persada, 2008 
Boediono, Seri Sinopsis Pengantar Ilmu Ekonomi No.2: Ekonomi Makro, Yogyakarta: Penerbit BPFE UGM,1997) hlm. 97.

Dwi Priyatno, Cara Kilat Brlajar Analisis Data Dengan SPSS 20, Yogyakarta: CV. Andi Offiset, 2012

Dwi Swiknyo, Analisis Laporan Keuangan Perbankan Syariah, Yogyakarta: Pustaka Belajar

Frianto Pandia, Manajemen Dana dan Kesehatan Bank, Jakarta: Rineka Cipta, 2012

Harmono, Manajemen Keungan ; Berbasis Balanced Scorecard, Jakarta: Bumi Aksara, 2009

Jimmy Hasoloan, Ekonomi Moneter, Yogyakarta: deepublish, 2014

Kasmir, Analisis Laporan Keuangan, Jakarta: Rajawali Persada, 2013

Ktut Silvana, Bank dan Lembaga Keuangan Lain, Jakarta: Erlangga, 2009

Malayu Hasibuan, Dasar-dasar Perbankan, Jakarta: Bumi Aksara, 2002

Nopirin, Ekonomi Moneter , Yogyakarta: BPFE UGM,1996

Nurul huda, Ekonomi Makro Islam Pendekatan Teoritis, Jakarta: PT. RajaGrafindo Persada, 2004
POINT Vol. 1, No. 1, Jul 2020

Sadono Sukirno, Ekonomi Pembangunan: Proses, Masalah, dan Dasar Kebijakan, Edisi Kedua, Jakarta: Penerbit Kencana Prenadam Media Group, 2006

Makro Ekonomi :Teori Pengantar, Jakarta: PT RajaGrafindo Persada, 2013

Sofyan Syafri Harahap, Analisis Laporan Keuangan, Jakarta: Raja Grafindo Persada, 2004

Amirus Sodiq, "Analisis Pengaruh Inflasi, Produk Dosmetic Bruto dan Jumlah Uang Beredar Terhadap Return On Asset Bank Syariah." Jurnal Equilibrium, Volume 2, No. 2, Desember 2014

Anto \& M. Ghafur Wibowo, "Faktor-Faktor Penentu Tingkat Profitabilitas Bank Umum Syariah Di Indonesia", La-Riba Jurnal Ekonomi Islam volume 6, No. 2 , Desember 2012

Aris Putrama, " Pengaruh Variabel Makro Ekonomi Terhadap Profitabilitas Bank Non Devisa di Indonesia Periode 2012-2016." Jurnal IImu Manajemen Volume 5, No. 2, 2017

Ayu Yanita Sahara, "Analisis Pengaruh Inflasi, Suku Bunga $\mathrm{BI}$, dan Produk Domestik Bruto Terhadap Return On Asset (ROA) Bank Syariah Di Indonesia", Jurnal Ilmu Manajemen, Volume 1 No. 1, Januari 2013

Fretty Welta dan Lemiyana, "Pengaruh CAR, Inflasi, Nilai Tukar Terhadap Profitabilitas Pada Bank Umum Syariah", I-Finance Volume 1, No.1 Juli 2017 